\title{
Mediterranean agriculture under climate change: adaptive capacity, adaptation, and ethics
}

Article

Accepted Version

Grasso, M. and Feola, G. (2012) Mediterranean agriculture under climate change: adaptive capacity, adaptation, and ethics. Regional Environmental Change, 12 (3). pp. 607-618. ISSN 1436-378X doi: https://doi.org/10.1007/s10113-0110274-1 Available at https://centaur.reading.ac.uk/25989/

It is advisable to refer to the publisher's version if you intend to cite from the work. See Guidance on citing.

Published version at: http://www.springerlink.com/content/77128m4774586456/

To link to this article DOI: http://dx.doi.org/10.1007/s10113-011-0274-1

Publisher: Springer Verlag

Publisher statement: The original publication is available at www.springerlink.com

All outputs in CentAUR are protected by Intellectual Property Rights law, including copyright law. Copyright and IPR is retained by the creators or other copyright holders. Terms and conditions for use of this material are defined in the End User Agreement.

www.reading.ac.uk/centaur

\section{CentAUR}


Central Archive at the University of Reading

Reading's research outputs online 


\title{
Mediterranean agriculture under climate change: adaptive capacity, adaptation, and ethics
}

Marco Grasso, marco.grasso@unimib.it (1)

Giuseppe Feola (2)

(1) Dipartimento di Sociologia e Ricerca Sociale, Università degli Studi di Milano-Bicocca, Milano, Italy

(2) Department of Geography and Environmental Science, University of Reading, Reading, UK

\begin{abstract}
In the coming decades the Mediterranean region is expected to experience various climate impacts with negative consequences on agricultural systems and which will cause uneven reductions in agricultural production. By and large, the impacts of climate change on Mediterranean agriculture will be heavier for southern areas of the region. This unbalanced distribution of negative impacts underscores the significance and role of ethical considerations in such a context of analysis. Consequently, the aim of this article is to justify and develop an ethical approach to agricultural adaptation in the Mediterranean and to derive the consequent implications for adaptation policy in the region. In particular, we define an index of adaptive capacity for the agricultural systems of the Mediterranean region on whose basis it is possible to group its different sub-regions, and we provide an overview of the suitable adaptation actions and policies for the sub-regions identified. We then vindicate and put forward an ethical approach to agricultural adaptation, highlighting the implications for the Mediterranean region and the limitations of such an ethical framework. Finally, we emphasise the broader potential of ethical analysis for agricultural adaptation policy.
\end{abstract}

Keywords: Adaptation, Adaptive Capacity, Agriculture, Climate Change, Ethics, Mediterranean Region 


\section{Introduction}

The harmful effects of global climate change on agriculture are unevenly distributed across regions, countries, and areas within countries because they depend on local physical and environmental conditions (Ferrara et al 2009, Giorgi and Lionello 2008, Giorgi et al 2004), and on the sensitivity, vulnerability and adaptive capacity of different natural and social systems (Brooks et al 2005, Smit and Skinner 2002). Climate change will significantly influence agricultural production in the coming decades (Cline 2007, Olesen and Bindi 2002); and, possibly, current climatic patterns are already impacting on specific agro-ecosystems and crops (Ben Mohamed et al 2002, Nicholls 1996).

Existing scientific research clearly indicates that climate change, besides having strong negative impacts on agriculture in developing countries (Cline 2007), will largely affect Southern Europe (Olesen and Bindi 2002). Specifically, this region is expected to experience severe negative effects on yield for many crop species (Iglesias et al 2009, Magnan et al 2009, Giannakopoulos et al 2005, Maracchi et al 2005). Despite the high variability of effects expected in different sub-regions and for different crop species, countries in Southern Europe are deemed to have more in common with other nonEuropean countries in the Mediterranean region than with countries in Northern Europe (Giannakopoulos et al 2009, 2005). In short, agriculture in the entire Mediterranean basin is going to suffer severely from climate change (Iglesias et al 2011, Giannakopoulos et al 2009).

Between 2031 and 2090, the Mediterranean region is expected to experience various climate impacts with negative consequences on agricultural systems (Giorgi and Lionello 2008). An increase in water stress would be particularly serious, as the region is already experiencing water shortages due to climatic conditions and to an often-inefficient water management system (Iglesias et al 2011, Rodriguez-Diaz and Topcu 2010, Magnan et al 2009). Other expected effects include the increased frequency of extreme meteorological events (Giannakopoulos et al 2005, Maracchi et al 2005), increased interannual climatic variability (Maracchi et al 2005), reduction of suitable areas for traditional crops (Maracchi et al 2005), sea level rise, increased soil salinity, and coastal erosion (Iglesias et al 2011, Sánchez-Arcilla 2011).

Furthermore, these climatic impacts are expected to cause a substantially uneven reduction in agricultural production. Iglesias et al (2009) used crop yield functions to estimate a 
yield variation, in the time frame between 2071 and 2100, in the range of $-22 \%$ to $0 \%$ for the Mediterranean North. In the Mediterranean South, the estimated range is between $27 \%$ and $5 \%$, depending on the climate scenario considered. ${ }^{1}$ Importantly, the reduction of agricultural production is expected to differ across sub-regions (e.g., Mediterranean North or South), crops, and seasons (Giannakopoulos et al 2009, Cline 2007) as shown by Table 5 in the Appendix.

It therefore seems likely that the impacts of climate change and variability on Mediterranean agriculture will be heavier in southern areas. This unbalanced distribution of negative effects makes Mediterranean agriculture a particular sensitive and controversial context. Hence, in our view, it emphasises the role and potential of ethical analysis, which is still infrequent in the current literature. Ethical considerations, in fact, imply greater legitimacy and can persuade parties with conflicting interests to cooperate more closely on collective actions.

This article, therefore, aims to investigate the fundamental ethical issues raised by adaptation to climate change in Mediterranean agriculture. In particular, we intend clearly to identify i) the subjects of justice in the context of the considered agricultural systems, ii) the principles of distribution that justify the moral duties and rights of subjects of justice, and iii) the types of adaptation-related burdens and benefits that should be shared fairly among subjects of justice.

To this end, we argue that a regional perspective is more likely to account for the ethical traits, characteristics and needs of Mediterranean agriculture because of its greater ability, as compared to a global perspective, to include local specificities and the consequent plurality of interests and objectives of the subjects involved. This standpoint, moreover, would reduce the complexity of adaptation policies due to the more limited number of parties involved, and the consequent less cumbersome bureaucratic and administrative requirements; and it would ultimately have a higher chance of success (Liverman and Ingram 2010). States, in fact, are expected to have more incentives to enter into a regional agreement rather than a global one, because the former can reflect local exigencies more closely, reduce risks of non-cooperation, and lower transaction costs (Asheim et al 2003).

\footnotetext{
1 These estimates already include the direct positive effects of carbon dioxide $\left(\mathrm{CO}_{2}\right)$ on crops, the rain-fed and irrigated simulations in each district, changes in crop distribution in the scenario due to modified crop suitability under the warmer climate, and endogenous adaptation.
} 
We are nonetheless aware of the limitations of our regional analysis, which for a comprehensive grasp should take account of institutional considerations, precluded here by space constraints. Nevertheless, our study indicates that an ethical focus, i.e. the investigation of the three constituents of distributive justice mentioned above, on Mediterranean agricultural systems makes it possible to develop fresh, wide-ranging, and more acceptable and feasible approaches to agricultural adaptation policy in the region.

In particular, section 2 of the article defines an index of adaptive capacity for the agricultural systems of the Mediterranean region on whose basis it is possible to group its different sub-regions. Section 3 provides an overview of the suitable adaptation actions and policies for the sub-regions identified in section 2. Section 4 explores and vindicates the constituents of distributive justice in relation to adaptation, and it develops an ethical framework in which to analyse and contextualize Mediterranean agricultural adaptation. Section 5 discusses the implications of such an ethical framework on Mediterranean agricultural adaptation and sets out its main limitations. The conclusive section 6 emphasises the broader potential of ethical analysis for agricultural adaptation policy.

\section{The adaptive capacity index}

\subsection{Methodology}

Although some indicator sets and indices have been proposed to assess adaptive capacity in agriculture (e.g., Iglesias et al 2011, Iglesias et al 2009, Tubiello and Rosenzweig 2008, Swanson et al 2007), there are no agreed-upon and uncontroversial measures of adaptive capacity in agriculture (Reidsma et al 2009).

The present study is largely based on the adaptive capacity index (ACI) approach proposed by Swanson et al (2007), which in its turn is based on the index of Smit et al (2001). We have privileged this approach for a number of reasons: i) it proposes a comprehensive and theoretically-based framework for analysis; ii) it specifically targets adaptive capacity in agricultural systems; iii) it can be operationalized through secondary data sources and thus does not need direct data collection; iv) its main strength lies in the relative comparison of geographical units with respect to widely agreed-upon determinants of adaptive capacity, thus providing basic information for the prioritizing of adaptation options. 
The ACI is defined by the performance of the agricultural system in relation to six determinants named, according to the original work of Smit et al (2001): economic resources, technology, information and skills, infrastructure, institutions, and equity (see also Table 6 in the Appendix). To our knowledge, this is the first study attempting to measure adaptive capacity in agriculture for the entire Mediterranean region.

These six determinants are operationalized through twelve indicators, and each determinant is associated with two indicators. The selection of the attributes is based on the literature (Iglesias et al 2011 Swanson et al 2007, Smit et al 2001) and on data availability (Table 1).

[Table 1 about here]

The main objectives of the ACI are identification of the adaptive capacities of national agricultural systems (NAS) and comparative exploration of their determinants. This index therefore does not give an absolute measure of adaptive capacity, but rather compares and ranks the NAS considered, thereby pointing out which countries might warrant further and more detailed analysis on the determinants or aspects considered.

The ACI index is calculated by normalizing the values of the indicators according to the following formulas:

Normalized value (higher is better) $=($ value for the NAS to be normalized - minimum value for all NASs) / (maximum value for all NASs - minimum value for all NASs) (Equation 1)

Normalized value (lower is better) $=1-[$ (value for the NAS to be normalized - minimum value for all NASs) / (maximum value for all NASs - minimum value for all NASs)](Equation 2)

The normalized values for each indicator are first aggregated by determinant, and then in the total ACI, as the average of the normalized values (Swanson et al 2007). This progressive aggregation procedure makes it possible to define an overall index. At the same time it guarantees transparency by making the rankings of each determinant visible. Furthermore, we carried out a sensitivity analysis to test the robustness of the rankings under five different weighting systems (see Appendix). Because no significant differences 
were observed, the results presented here refer to the baseline case, in which equal weight is adopted for each indicator and determinant.

The ACI index is calculated for four groups of Mediterranean countries: i) North Mediterranean countries belonging to the European Union (NM-EU: Cyprus, France, Greece, Italy, Malta, Portugal, Slovenia, and Spain); ii) North Mediterranean countries not belonging to the European Union (NM: Albania, Bosnia and Herzegovina, Croatia, Macedonia FYR, Montenegro, Serbia, and Turkey); iii) Middle Eastern countries (ME: Israel, Jordan, Lebanon, and Syrian Arab Republic); and iv) North African countries (NA: Algeria, Egypt, Libyan Arab Jamahiriya, Morocco, and Tunisia).

\subsection{Results}

The ranking for the total ACI shows a clear divide between the North Mediterranean countries belonging to the EU and the Middle Eastern and North African countries (Table 2). France and Portugal stand out among the North Mediterranean countries, the former being the country with the highest index, the latter with the lowest index, within this subregion. Among the remaining countries, some minor differences can be observed between North Mediterranean countries not belonging to the EU and the North African and Middle Eastern ones, although only Morocco stands out at a significant level (negatively) from this group.

[Table 2 about here]

The analysis of the rankings of the ACI individual determinants allows us to identify those that most influence the ranking of the total ACI: namely economic resources, information and skills, institutions and networks, and equity. The rankings of these determinants are both more skewed than the remaining ones and show a high tendency to cluster by subregions. Specifically, NM-EU countries consistently rank higher than almost all other countries. In other words, NM-EU countries perform better than other countries in regard to: i) value added produced (per worker and per capita unit), with the partial exception of Portugal and Cyprus, which show very low levels of productivity per worker unit; ii) educational level and access to information, where also Israel, Croatia, Lebanon and Jordan perform relatively well, especially the latter two because of relatively high levels of tertiary education; iii) government effectiveness and social networks, where again also 
Israel and Croatia perform relatively well; and iv) Gini index and health expenditure, where Croatia and Serbia also perform relatively well, and Turkey performs relatively poorly, mainly because of a low per capita health expenditure. These soft determinants, i.e. those related to social components such as information and skills, institutions and networks and equity, in many cases facilitate or serve as prerequisites for hard ones such as technical exposure.

The rankings of the ACI values of two determinants, technology and infrastructure, are partly inconsistent with the total ACI ranking. As far as technology is concerned, this mirrors the fact that some countries have a small agricultural area and high technological levels in terms of machinery (e.g., Slovenia) or of irrigation equipment (e.g., Egypt). On the other hand, countries such as France, which if taken in their entirety make less use of irrigation equipment, perform relatively poorly. In regard to infrastructure, Greece and Portugal perform relatively poorly due to relatively high levels of water withdrawal and low levels of agricultural area per capita. Consequently, these two countries' rankings resemble that of NA and ME ones, more than that of NM ones.

[Table 3 about here]

\section{Agricultural adaptation to climate change in the Mediterranean region}

The ACI suggests that, in general terms, there is a marked North-South divide in the Mediterranean region, where North African and Middle Eastern countries seem to be rather similar to each other. These results confirm those of previous studies. Iglesias et al (2011), for example, compared six countries in the Mediterranean basin and estimated that NA countries (Egypt, Tunisia, Morocco and Libya) have a significantly lower adaptive capacity than NM ones (France, Spain). Our results, obtained with a different index of adaptive capacity, suggest that this gap characterizes the entire Mediterranean basin.

The ACI also suggests that the North-South divide depends largely on soft determinants (information and skills, institutions and networks, equity) and on economic resources. From a technological and infrastructural perspective, the difference between North and South Mediterranean countries is less manifest. Therefore the soft determinants may represent key entry points for increasing adaptive capacity in the NA and ME countries. 
However, whilst a wide set of potentially applicable adaptation policies exist, the task of identifying appropriate adaptation options with respect to these determinants is complicated by several factors. They include: i) the uncertainty of impacts and of adaptation capacity, which makes planning and cost-benefit analysis difficult (e.g., Adger and Vincent 2005); ii) the different potential scales of intervention (from local to global), which often have unpredictable cross-level feedbacks (e.g., Ericksen 2008); and iii) the existence of different stakeholders or subjects with specific interests and needs to be negotiated and reconciled within existing or potentially novel institutional settings (e.g., Rodriguez-Diaz and Topcu 2010, Ericksen 2008).

Thus considered, adaptation initiatives for NA and ME countries could ideally include a mix of different options targeting the soft determinants, such as measures to stabilize farm income through crop insurance, crop shares and futures, and diversification of household activities (especially in the case of smallholders) (AEA Energy \& Environment and Universidad Politécnica de Madrid 2007, Smit and Skinner 2002). The information and skills gap could be targeted through services advising farmers on how to adapt farming practices or use new crops and disseminating good practices and technical information (Battaglini et al 2009, AEA Energy \& Environment and Universida Politécnica de Madrid 2007). In addition, non-agriculture related programs targeting ethical issues or education as a driver of social development might also be expected to exert a positive effect on adaptive capacity in rural communities and among the smallhold farming households which characterize many countries in the Southern Mediterranean basin (Lutz 2009).

As noted above, from a technological and infrastructural perspective (e.g., water availability), the difference between North and South Mediterranean countries is less apparent. This is especially true if the southernmost areas of NM countries are considered, instead of the entire country (e.g., Italy, France, and Spain). In this respect, especially for issues such as water availability, it seems impossible to identify geographical differences, and it is instead more appropriate to talk of issues widespread at a regional (i.e., Mediterranean) level.

However, this does not imply that the same adaptation options might be equally appropriate in different countries and sub-regions within each country. In fact, adaptation measures should fit the diverse institutional settings and the productive and socioeconomic characteristics that are found in different contexts. For example, water 
management is usually carried out at a local level (e.g., water basin); and local variation in both pedoclimatic and productive conditions can be significant.

Thus, for all countries in the Mediterranean region, many adaptation options might be possible from a technological and infrastructural perspective. These options include a shift in sowing dates, the planting of different genotypes, a change in inputs, water conservation measures (e.g., Olesen and Bindi 2002), the improvement of water supply infrastructure, regional or basin water management and drought management plans, an increase in irrigation or substitute rain-fed with irrigation systems, an increase in energy efficiency, and the improvement of weather forecast and information systems (e.g., Bindi and Olesen 2011, Iglesias et al 2011, Howden et al 2007, Maracchi et al 2005, Olesen and Bindi 2002, Tubiello et al 2000).

These examples of adaptations differ in several respects, importantly including the role that different actors may take in the different stages of promotion, funding, implementation and assessment of the adaptation measure. For instance, in the adoption of water conservation measures, farmers, farmer organizations, governments, and international organizations might all play a role, such as testing and implementing technology (farmers), promoting knowledge exchange (farmer organizations), funding and incentives in new technologies (governments), and the funding of research programs and knowledge exchange (international organizations).

Ultimately, the different adaptation needs and adaptive capacities of the areas to which these actors belong make them, as pointed out in the ensuing section, subjects of justice in agricultural adaptation. We therefore need to understand how such subjects of justice should respond to the important ethical issues entailed by the unequal impacts of climate change and variability on Mediterranean agriculture, and eventually make clear the consequent implications for adaptation initiatives in the region.

\section{Ethical analysis of agricultural adaptation in the Mediterranean context}

As anticipated, an ethical analysis of agricultural adaptation has seldom been carried out and, to our knowledge, never conducted for the Mediterranean region. However, given the unbalanced distribution of climate impacts and the diversity of Mediterranean agricultural systems and of the relevant actors, an ethical analysis would be of great benefit to the understanding of the adaptations needed by the agricultural systems of the region, and of their eventual implications for the development of more effective policy initiatives. 
In order to carry out an ethical analysis of agricultural adaptation in the Mediterranean, it is convenient to organize our argument around the three constituents of distributive justice anticipated in the introduction - i) subjects of justice; ii) principles of distribution; iii) types of burdens and benefits - according to a liberal theoretical perspective. In fact, despite the controversies that such a standpoint may raise in relation to environmental issues (Mason 2008), we maintain, consistently with the most authoritative climate ethics literature (e.g., Shue 2011, 1993, Caney 2010, 2009, Gardiner 2010, 2004, Moellendorf 2009, Miller 2008, Jamieson 2005, Singer 2002), that liberalism, by claiming that its central moral tenet is that stronger subjects should support and assist weaker, vulnerable ones (Dworkin 1978), can authoritatively frame ethical approaches to global environmental issues (Miller 1999) and in particular to climate change (Calder and McKinnon 2011). Specifically, owing to the characteristics of Mediterranean agricultural systems, a liberal approach to the constituents of distributive justice is, in our opinion, extremely useful for grasping some of the most urgent ethical implications entailed by agricultural adaptation in the region, and eventually to derive arguments that are useful for policy-making.

Distributive justice by and large relates to the distribution of burdens and benefits in society, and it can be articulated, as said, into three closely intertwined questions: i) What are the subjects of justice? ii) What is/are the principle/s of distribution? iii) What types of burdens and benefits are to be justly shared? (Caney 2005). In what follows, we analyse from a liberal standpoint each of these constituents of distributive justice in relation to Mediterranean agricultural systems and consistently with the considerations put forward concerning their adaptive capacities and consequent adaptation needs, with the ultimate objective of improving the effectiveness of agricultural adaptation policy in our context of analysis.

As far as the first constituent of distributive justice is concerned (specification of subjects of justice) we deem that - owing to the characteristics of adaptive capacities and to the consequent nature of the required adaptations by Mediterranean agricultural systems - two general claims of liberalism must be defended and contextualized in order to identify the relevant (groups of) subjects of justice: 1) more advantaged subjects should bear the burden of adaptation; 2) less advantaged subjects should be assured privileged access to adaptations (Grasso 2010b). It is worth pointing out that vindication of these two claims 
also concerns the second constituent of distributive justice (the distributive principle), whereas the third one (the types of burdens and benefits) requires close scrutiny of the context of analysis and therefore will be addressed in section 5, when we discuss the implications of the ethical analysis for Mediterranean agricultural adaptation.

The first claim (more advantaged subjects should bear the burden of adaptation) entails, in this context of analysis, the Ability to Pay distribution principle. This is a forward-looking principle grounded in no-fault forms of prospective responsibility (Shue 1993) based on the capacity (in terms of institutions, technology, infrastructures, skills) and the wealth (in terms of welfare levels) of subjects, which ultimately justifies also remedial duties. In practice, the Ability to Pay principle requires that the most advantaged subjects bear the largest quota of adaptation burdens because of their greater wealth and capacities. We call these subjects contributors.

The second claim (privileging those who are most in need of adaptation) refers instead to the Lack of Adaptive Capacity principle of distribution. It identifies, on the one hand, a minimum level of adaptive capacity. This is a level below a moral threshold between those who have enough and those who have not enough adaptive capacity to perform the basic adaptation activities ensuring that agricultural systems provide a decent life. On the other hand, the principle in question recognises adaptive capacity levels that extend beyond that moral threshold. The objective of this principle is to allow those subjects of justice below the moral threshold of adaptive capacity to be supported in carrying out the agricultural adaptations necessary to pursue a decent life. We call these subjects recipients.

It is important to note that, despite the state-level perspective of the ACI, on empirical grounds subjects of justice are not only states. In fact, in order to frame our ethical analysis, we attribute to national and sub-national subjects of justice the level of the ACI index of the country to which they belong. In other words, the possibility of an ethical analysis requires that relevant subjects of justice be considered as having the same degree of adaptive capacity as their respective state, or, more precisely, as their NAS.

That said, we maintain that, in practical terms, the ethically relevant subjects of justice in agricultural adaptation are farmers (both family and industrial), producer organizations, national governments, non-governmental organizations (NGOs), and international institutions. Their ethical status is substantiated by the principles of justice of Ability to Pay and of Lack of Adaptive Capacity put forward and which, respectively, specify their 
moral role as contributors or recipients of adaptation duties and rights (i.e., in practice, a duty to support adaptation and a right to adaptation assistance).

In light of the ACI evaluation, and in particular of the role and dynamics of soft determinants of adaptive capacity that it emphasises, it seems possible to claim that the duties and rights of the above-specified subjects of justice vary among the different areas of the Mediterranean region. In our view, the subjects of justice central for confronting the North-South disparities in terms of soft determinants of adaptive capacity in the region considered are family and industrial farmers, producer organizations and national governments, with the proviso that farmers should not be considered contributors because of their relative (i.e., in comparison with the other subjects of justice) limited capacity and wealth, which exclude the moral mandate of the Ability to Pay principle.

According to our moral argument, these subjects of justice, when located in the southern Mediterranean region (NA and ME countries), are ethically entitled to adaptation assistance owing to their scant adaptive capacity as demanded by the principle of Lack of Adaptive Capacity. In particular, farmers should be primary recipients of adaptation assistance, whereas producer organizations and national governments have an indirect right to receive assistance, meaning they are entitled to it only in virtue of their capacity to target it more effectively on farmers, the main subjects of justice. Producer organizations and national governments of Northern countries, instead, owing to their greater capacity and wealth, should be morally held to be contributors, as required by the Ability to Pay principle. At the same time, we believe that Northern NGOs and international organizations might play a non-marginal role in increasing adaptive capacity and promoting adaptation in the Mediterranean region. In this regard we argue that they have an indirect duty to contribute owing to their capacity to represent and express the implicit obligations of adaptation assistance incumbent on wealthier Northern societies.

To summarize, the ethical framework envisioned, and synthesised in Table 4, holds that farmers in Northern countries are not morally entitled to adaptation assistance, whereas those of the NA-ME countries are morally eligible for it. North producer organizations and national governments are morally obliged to be contributors, whilst Southern ones are recipients. Furthermore, adaptation assistance is due to recipient subjects of justice also from NGOs and international organizations in their representative role. 
[Table 4 about here]

\section{Discussion}

\subsection{Implications of ethical analysis for agricultural adaptation}

The ethical analysis carried out has a manifest normative slant. As a consequence, it simply justifies the existence of subjects of justice and the role that they ought to play in the context of analysis consistently with their mutual status in regard to the principles of justice specified. The analysis therefore has no ambition to stipulate binding obligations, whose exploration would need - as highlighted in the introduction and emphasized below - an institutional approach, which would in any case fall outside the scope of this article. Nonetheless, the ethical framework outlined in Table 4 provides valuable suggestions, as clearly shown, for instance, by the consideration of adaptation measures on the adaptive capacity determinants of economic resources and information and skills, which are particularly weak in Southern Mediterranean countries. In this regard, our framework suggests, in fact, a possible effective strategy: national governments and NGOs and international organizations in NM countries would have a moral obligation to support adaptation by Southern farmers and farmer organizations through measures such as educational programs to enhance information and skills and crop insurance schemes to support producer units economically in the case of adverse weather events.

Furthermore, the categorization of subjects of justice and the specification of their ethical duties and rights also make it possible to stipulate the types of burdens and benefits that should be distributed, this being the third constituent of distributive justice highlighted in the previous section. In general, the elements to be distributed take the form of in-cash or in-kind adaptation assistance. In relation to our context of analysis, we maintain that adaptation funding, namely in-cash assistance, is crucial for implementing adaptation initiatives in Mediterranean agriculture. At the same time, as pointed out in section 3, also in-kind technology transfer and - especially due to the soft nature of the main determinants of adaptive capacity - scientific and knowledge transfer are crucial elements of adaptive capacity. In this regard, our ethical analysis yields a further, significant, insight. The soft nature of the main determinants of adaptive capacity makes, in the case of family farmers, in-kind transfer superior to in-cash one. Adaptation assistance targeted on 
them should therefore take primarily the form of technology, scientific and knowledge transfer, owing to the lower capacity of family farmers to turn cash into proper adaptation activities. This paternalistic recommendation is justified on the basis of problems of preference interdependence of individuals (i.e., the likely indulgence in the consumption of vices by poorly-educated individuals) and of the possibilities of externalities (Currie and Gahvari 2008, Thurow 1974). On the contrary, adaptation assistance targeted on industrial farmers, producer organizations and national governments, should preferably take the form of in-cash transfer, owing to the expected superior capacity of these organizations to invest in appropriate adaptations, and to their predominantly fundschannelling role. For instance, in regard to water availability (technological and infrastructural determinants of adaptive capacity) for family farmers in Southern Mediterranean countries, our analysis envisions a particular set of priorities such as the provision of information about the possibility of shifting sowing dates, about new genotypes or enhanced weather forecasts, or the improvement of water distribution infrastructure. These in-kind transfers are preferable to a system of (in-cash) incentives for modifying water usage patterns.

To briefly recap the entire argument, our ethical framework holds that, in regard to the distribution of burdens and benefits of Mediterranean agricultural adaptation among farmers, producer organizations and national governments, the most suitable liberal principles of distributive justice are Ability to Pay and Lack of Adaptive Capacity. The former principle responds to the claim that more advantaged subjects - namely Northern producers organizations, governments, and NGOs and international organizations - should provide adaptation assistance because they have the possibility and the means to do so. The second requires that weaker subjects of justice - Southern farmers, producer organizations and governments - should be assisted according to their level of adaptive capacity: the lower that level, the larger the assistance morally owed, and which in the case of Southern family farmers this assistance should preferably be in-kind.

\subsection{Limitations and future work}

Despite the novel, in our opinion, insights into Mediterranean agricultural adaptation and its policy afforded by our ethical analysis, we are aware of its main limitations. In fact, when considering the overall ethical picture, it would also be necessary to bear in mind the procedural (or formal, or abstract) notion of justice (Grasso and Sacchi 2011, Gardiner 
2010, Grasso 2010b, Albin 2003). This concerns the fairness of the process by which the distribution of burdens and benefits is attainable and relates to the participation and recognition of all actors involved in decisional processes, as well as to the distribution of power among them. However, this issue is not covered here so as to maintain our argument within reasonable bounds.

More importantly, in a broader understanding, a fully comprehensive specification of our ethical approach to Mediterranean agriculture would also need an institutional analysis, as anticipated in the introduction. This is not dealt with here because an institutional perspective would require attentive scrutiny of regional structures and mechanisms governing climate change and its policy, which has not been possible in this article because of obvious space constraints. However, we believe that the current study can inform such analysis, in that it discusses the founding elements that may serve as a basis for a more specific policy debate among the regional subjects concerned. We therefore maintain that the institutional approach is definitely a relevant avenue for future research.

A final limitation concerns the ACI itself. In particular, the proposed index presents an aggregate picture of national agricultural systems in the Mediterranean countries. This methodological approach was adopted because of its functionality to the ethical analysis carried out, and in particular to its regional approach, justified from the environmental, cultural, and governance perspectives (Liverman and Ingram 2010, Asheim et al 2003). Adoption of an aggregate measure of adaptive capacity was also made necessary by the limited availability of reliable and comparable data at a more disaggregated level for the entire Mediterranean region. A drawback of this approach, however, is that it does not appropriately render the variability that exists among agricultural systems at sub-national and local level. An interesting possibility for future research is therefore more detailed investigation of such local differences adopting a wider spectrum of research tools, including qualitative research. We envision that the ACI, appropriately applied at a lower spatial scale, can function as an exploratory tool with which, for example, to identify hotspots, and thus inform a more qualitative analysis of adaptive capacity at local level.

\section{Conclusions}

What conclusions might be drawn from analysis of the characteristics of Mediterranean agriculture adaptive capacity and adaptation and from the ethical considerations that have 
been consequently raised? How might these reflections apply to adaptation policy in agriculture?

We have assumed that the unbalanced impacts of climate change on Mediterranean agriculture emphasise the role and potential of ethical analysis. Hence our main aim has been to vindicate and develop an ethics-based framework on agricultural adaptation in the region. In this regard we believe that, by and large, the article has shown the critical, yet greatly neglected, relevance of ethical considerations when dealing with adaptation in agriculture. In fact, we have argued that framing agricultural adaptation through reference to ethical considerations can greatly improve the acceptability and political feasibility of its dynamics, in regard to both contribution (i.e. duties) and assistance (i.e. rights). In particular, the ethical analysis carried out fundamentally makes it possible to argue that, in the Mediterranean context, in regard to adaptation assistance, Northern producer organizations, governments and NGOs and international organizations are duty-bearers, whereas Southern farmers, producers organizations and governments are, respectively, morally entitled to in-kind and in-cash assistance.

In short, inclusion of the ethical dimension may help remedy the cleavages caused by the different perspectives on the nature of adaptation in agriculture, and it may mitigate the consequent conflicts among interests, so that the harm inflicted by climate change on a sensitive sector such as agriculture can be effectively addressed. Hence, in the case of a difficult issue like this, it seems that reference to the moral dimension would provide a useful underpinning for international initiatives, especially in regard to the necessary involvement of poorer countries in the broader climate debate (Grasso 2010a). Eventually, we believe that, in regions characterized by high degrees of inequalities such as the Mediterranean basin, ethical considerations might also provide reasoned elements for debate among regional stakeholders with regard to the development of an agreed-upon framework to confront agricultural adaptation and devise coherent and unified regimes. Otherwise, the emerging hectic system, in which the notion of adaptation itself is fragmented and unclear, let alone its agricultural specification, will lead to the ineffective use of resources and to poor adaptation practices, which are detrimental to agricultural systems. 


\section{Acknowledgments}

The authors thank Christian Baatz and two anonymous referees for their comments on previous versions of this manuscript. 


\section{References}

Adger WN, Vincent K (2005) Uncertainty in adaptive capacity. C R Geosci 337(4): 399410

Albin C (2003) Negotiating international cooperation: global public goods and fairness. Rev Int Stud 29: 365-385

AEA Energy \& Environment, Universidad de Politécnica de Madrid (2007) Adaptation to climate change in the agricultural sector. Report to European Commission Directorate General for Agriculture and Rural Development

Asheim GB, Bretteville Froyn C, Hove J, Menz FC (2003) Regional versus global cooperation for climate control. J Environ Econ Manag 51: 93-109

Ben Mohamed A, van Duivenbooden N, Abdoussallam S (2002) Impact of climate change on agricultural production in the Sahel - Part 1. Methodological approach and case Study for Millet in Niger. Climatic Change 54(3): 327-348

Bindi M, and Olesen JE (2010) The responses of agriculture in Europe to climate change. Reg Environ Change 11(S1): 151-158

Brooks N, Adger WN, Kelly PM (2005) The determinants of vulnerability and adaptive capacity at the national level and the implications for adaptation. Global Environ Change 15: 151-163

Caney S (2005) Justice beyond borders. A global political theory. Oxford University Press, Oxford

Caney S (2009) Justice and the distribution of greenhouse gas emissions. J Global Ethics 5(2): $125-46$

Caney S (2010) Climate change and the duties of the advantaged. Crit Rev Int Soc Polit Philos 13(1): 203-28

Calder G, McKinnon C (eds) (2011) Climate change and liberal priorities. Routledge, Abingdon

Cline WR (2007) Global warming and agriculture. Impact estimated by country. Peterson Institute for International Economics, Washington 
Currie J, Gahvari F (2008) Transfers in cash and in-kind: theory meets the data. J Econ Lit 46(2): 333-383

Dworkin R. (1978) Liberalism. In: Hampshire S (ed) Public and private morality. Cambridge University Press, Cambridge

Ericksen P (2008) Conceptualizing food systems for global environmental change research. Global Environ Change 18(1): 234-245

Ferrara RM, Trevisiol P, Acutis M et al (2009) Topographic impacts on wheat yields under climate change: two contrasted case studies in Europe. Theor Appl Climatol 99(12): $53-65$

Fischer G, Shah MN, Tubiello FN, van Velhuizen H (2005) Socio-economic and climate change impacts on agriculture: an integrated assessment, 1990-2080. Philos T R Soc B: 360(1463): 2067-2083

Gardiner S (2004) Ethics and global climate change. Ethics 114: 555-600

Gardiner S (2010) Ethics and climate change: an introduction. WIREs Clim Change 1(1):54-66

Giannakopoulos C, Bindi M, Moriondo M, Tin T (2005) Climate change impacts in the Mediterranean resulting from a $2{ }^{\circ} \mathrm{C}$ global temperature rise. WWF, Gland

Giannakopoulos C, Le Sager P, Bindi M et al (2009) Climatic changes and associated impacts in the Mediterranean resulting from a $2{ }^{\circ} \mathrm{C}$ global warming. Glob Planet Change 68(3): 209-224

Giorgi F, Bi X, Pal J (2004) Mean, interannual variability and trends in a regional climate change experiment over Europe. II: climate change scenarios (2071-2100). Clim Dynam 23: $839-858$

Giorgi F, Lionello P (2008) Climate change projections for the Mediterranean region. Glob Planet Change 63: 90-104

Grasso M (2010a) An ethical approach to climate adaptation finance. Global Environ Change 20: 74-81

Grasso M (2010b) Justice in funding adaptation under the international climate change regime. Springer, Dordrecht 
Grasso M, Sacchi S (2011) Procedural justice in international negotiations on climate change. CISEPS Research Paper No. 6-2011, CISEPS, Milano

Howden SM, Soussana J-F, Tubiello FN et al (2007). Climate change and food security special feature: Adapting agriculture to climate change. PNAS 104(50): 19691-19696.

Iglesias A, Garrota L, Quiroga S, Moneo M 2009. Impacts of climate change in agriculture in Europe. PESETA-Agriculture study. JRC Scientific and technical Reports

Iglesias A, Mougou R, Moneo M, Quiroga S (2011) Towards adaptation of agriculture to climate change in the Mediterranean. Reg Environ Change 11(Suppl 1): 159-166

Keulartz J (2005) Kyoto and the ethics of flexibility. In: Vermeersch E (ed) Reading the Kyoto Protocol. Ethical aspects of the Convention on climate change. Eburon, Delft, pp $117-153$

Jamieson D (2005) Adaptation, mitigation and justice. In: Sinnott-Armstrong W and Howarth RB (eds) Perspectives on climate change: science, economics, politics, ethics. Elsevier, Oxford, pp 217-248

Liverman D and Ingram J (2010) Why regions? In: Ingram J, Ericksen P and Liverman D (eds) Food security and global environmental change. Earthscan, London-Washington, pp 203-211

Lutz W (2009) Sola schola et sanitate: human capital as the root cause and priority for international development? Philos T R Soc B 364(1532): 3031-3047

Magnan A, Garnaud B, Billé R et al (2009) The future of the Mediterranean: from impacts of climate change to adaptation issues. IDDRI, Paris

Maracchi G, Sirotenko O, Bindi M (2005) Impacts of present and future climate variability on agriculture and forestry in the temperate regions: Europe. Climatic Change 70: $117-135$

Mason M (2008) The governance of transnational environmental harm: addressing new modes of accountability/responsibility. Glob Environ Polit 8(3): 8-24

Miller D (1999) Social justice and environmental goods. In: Dobson A (ed) Fairness and futurity. Oxford University Press, Oxford, pp 151-172

Miller D (2008) Global justice and climate change: how should responsibilities be 
distributed? The Tanner Lectures on Human Values, Delivered at Tsinghua University, Beijing, March 24-25, 2008: 119-156

Moellendorf D (2009) Treaty norms and climate change mitigation. Ethics Int Aff 23(3): 247-265

Nicholls RJ, Hoozemans FMJ (1996) The Mediterranean: vulnerability to coastal implications of climate change. Ocean Coast Manage 31(2-3): 105-132

Olesen JE, Bindi M (2002) Consequences of climate change for European agricultural productivity, land use and policy. Eur J Agron 16(4): 239-262

Reidsma P, Ewert F, Oude Lansink A, Leemans R (2009) Vulnerability and adaptation of European farmers: a multi-level analysis of yield and income responses to climate variability. Reg Environ Change 9: 25-40

Rodríguez-Díaz JA, Topcu S (2010). Sustaining Mediterranean irrigated agriculture under a changing climate. Outlook Agr 39(4): 269-275

Sánchez-Arcilla A, Mösso C, Sierra JP et al (2011). Climatic drivers of potential hazards in Mediterranean coasts. Reg Environ Change 1: 617-636

Shue H (1993) Subsistence emissions and luxury emissions. Law Policy 15(1): 39-59

Shue H (2011) Human rights, climate change, and the trillionth ton. In: Arnold DG (ed) The ethics of global climate change. Cambridge University Press, Cambridge, pp 292-314 Singer P (2002) One atmosphere. In: Singer P One world: the ethics of globalization. Yale University Press, New Haven, Chapter 2, pp 14-50

Smit B, Skinner MW (2002). Adaptation options in agriculture to climate change: a typology. Mit Adapt Strat Glob Change 7(1): 85-114

Smit B, Pilifosova O et al (2001) Adaptation to climate change in the context of sustainable development and equity. In: McCarthy JJ, Canzianni OF, Leary NA et al (eds), Climate Change 2001: Impacts, adaptation, and vulnerability - Contribution of Working Group II to the Third Assessment Report of the IPCC. Cambridge University Press, Cambridge

Swanson D, Hiley J, Venema HD (2007) Indicators of adaptive capacity to climate change for agriculture in the Prairie region of Canada. IISD, Winnipeg 
Thurow LC (1974) Cash versus in-kind transfers. Am Econ Rev 64(2): 190-195

Tubiello FN, Rosenzweig C (2008) Developing climate change impact metrics for agriculture. The IAJ 8(1): 165-184

Tubiello FN, Donatelli M, Rosenzweig C, Stockle CO (2000) Effects of climate change and elevated $\mathrm{CO}_{2}$ on cropping systems: model predictions at two Italian locations. Eur $\mathbf{J}$ Agron 13(2-3): 179-189 
Table 1 - Indicators of the ACI

\begin{tabular}{|c|c|c|c|c|c|c|}
\hline Determinant & Attribute & Indicator & Unit & Better & Data source* & $\begin{array}{l}\text { Reference } \\
\text { period }\end{array}$ \\
\hline \multirow[t]{2}{*}{$\begin{array}{l}\text { Economic } \\
\text { resources }\end{array}$} & Income generation & $\begin{array}{l}\text { Agriculture value added } \\
\text { per worker }\end{array}$ & $\begin{array}{l}\text { Constant } 2000 \\
\text { USD }\end{array}$ & high & WB, FAO & 2007 \\
\hline & & $\begin{array}{l}\text { Agricultural value added } \\
\text { per capita } * 1000\end{array}$ & $\begin{array}{l}\text { Constant } 2000 \\
\text { USD }\end{array}$ & high & WB, OECD & 2007 \\
\hline \multirow[t]{2}{*}{ Technology } & $\begin{array}{l}\text { Technological } \\
\text { exposure }\end{array}$ & Agricultural machinery & $\begin{array}{l}\text { Tractors per } 100 \\
\text { sq. km of arable } \\
\text { land }\end{array}$ & high & FAO & 2007 \\
\hline & $\begin{array}{l}\text { Water access } \\
\text { technology }\end{array}$ & $\begin{array}{l}\text { Area equipped for } \\
\text { irrigation/Cultivated area }\end{array}$ & $\%$ & high & FAO & 2007 \\
\hline \multirow[t]{2}{*}{$\begin{array}{l}\text { Information and } \\
\text { skills }\end{array}$} & Education & $\begin{array}{l}\text { Students in tertiary } \\
\text { education } / 100,000 \\
\text { inhabitants }\end{array}$ & Number & high & UN & 2008 \\
\hline & $\begin{array}{l}\text { Access to } \\
\text { information }\end{array}$ & $\begin{array}{l}\text { Internet users/Total } \\
\text { population }\end{array}$ & $\%$ & high & $\mathrm{UN}$ & 2007 \\
\hline \multirow[t]{2}{*}{ Infrastructure } & Water resources & $\begin{array}{l}\text { Annual freshwater } \\
\text { withdrawals for } \\
\text { agriculture/Total } \\
\text { freshwater withdrawals }\end{array}$ & $\%$ & low & FAO & 2007 \\
\hline & Soil resources & Agricultural area & Ha per person & high & FAO, UN & 2007 \\
\hline \multirow[t]{2}{*}{$\begin{array}{l}\text { Institutions and } \\
\text { networks }\end{array}$} & $\begin{array}{l}\text { Effective } \\
\text { governance }\end{array}$ & $\begin{array}{l}\text { Government effectiveness } \\
\text { index }\end{array}$ & Dimensionless & high & WB & 2009 \\
\hline & Social networks & $\begin{array}{l}\text { Mobile phones } \\
\text { subscriptions } / 100 \\
\text { population }\end{array}$ & $\%$ & high & ITU, WB & 2008 \\
\hline \multirow[t]{2}{*}{ Equity } & Inequality & GINI index & Dimensionless & low & WB & 2010 \\
\hline & $\begin{array}{l}\text { Availability of } \\
\text { health care } \\
\text { resources }\end{array}$ & $\begin{array}{l}\text { Per capita total } \\
\text { expenditure on health at } \\
\text { average exchange rate }\end{array}$ & USD & high & WHO & 2006 \\
\hline
\end{tabular}

*WB: World Bank, FAO: Food and Agriculture Organization, UN: United Nations, ITU: International Telecommunication Union, WHO: World Health Organization 
Table 2 - Ranking of the total (ACI) ${ }^{2}$

\begin{tabular}{lcc}
\hline Country & Sub-region & Total ACI \\
\hline France & NM - EU & 0.721 \\
Italy & NM - EU & 0.620 \\
Spain & NM - EU & 0.562 \\
Greece & NM - EU & 0.559 \\
Portugal & NM - EU & 0.484 \\
Turkey & NM & 0.318 \\
Albania & NM & 0.315 \\
Egypt & NA & 0.282 \\
Tunisia & NA & 0.276 \\
Algeria & NA & 0.276 \\
Jordan & ME & 0.273 \\
Lebanon & ME & 0.259 \\
Morocco & NA & 0.197 \\
\hline
\end{tabular}

${ }^{2}$ The total ACI could be calculated only for a limited number of countries, i.e. those for which no data were missing for any determinant (see also Table 3 ). 
Table 3 - Rankings of the ACI for single determinants

\begin{tabular}{|c|c|c|c|c|c|}
\hline Country & Sub-region & $\begin{array}{l}\text { Index - } \\
\text { Economic } \\
\text { resources }\end{array}$ & Country & Sub-region & $\begin{array}{l}\text { Index- } \\
\text { Technology }\end{array}$ \\
\hline France & NM - EU & 0.887 & Egypt & NA & 0.525 \\
\hline Slovenia & NM - EU & 0.737 & Slovenia & $N M-E U$ & 0.509 \\
\hline Italy & $N M-E U$ & 0.621 & Italy & NM - EU & 0.432 \\
\hline Spain & NM - EU & 0.621 & Greece & $N M-E U$ & 0.323 \\
\hline Greece & $N M-E U$ & 0.529 & Portugal & $N M-E U$ & 0.312 \\
\hline Lebanon & ME & 0.465 & Albania & NM & 0.250 \\
\hline Croatia & NM & 0.457 & Cyprus & $N M-E U$ & 0.241 \\
\hline Turkey & NM & 0.349 & Macedonia, FYR & NA & 0.240 \\
\hline Portugal & $N M-E U$ & 0.331 & Lebanon & ME & 0.211 \\
\hline Cyprus & NM - EU & 0.327 & Jordan & ME & 0.206 \\
\hline Albania & NM & 0.290 & Croatia & NA & 0.191 \\
\hline Syrian Arab Republic & ME & 0.277 & Spain & $N M-E U$ & 0.170 \\
\hline Tunisia & NA & 0.239 & Syrian Arab Republic & ME & 0.141 \\
\hline Egypt & NA & 0.208 & Turkey & NA & 0.136 \\
\hline Bosnia and Herzegovina & NM & 0.208 & France & $N M-E U$ & 0.116 \\
\hline Morocco & NA & 0.175 & Morocco & NA & 0.082 \\
\hline Algeria & NA & 0.168 & Tunisia & NA & 0.047 \\
\hline Macedonia, FYR & NM & 0.153 & Algeria & NA & 0.041 \\
\hline Montenegro & NM & 0.110 & Bosnia and Herzegovina & NM & 0.020 \\
\hline Jordan & ME & 0.006 & $\begin{array}{l}\text { Israel } \\
\text { Intilizeguvila }\end{array}$ & & missing data \\
\hline Israel & & missing data & Libyan Arab Jamahiriya & & missing data \\
\hline Libyan Arab Jamahiriya & & missing data & $\begin{array}{l}\text { Malta } \\
\text { Matramina }\end{array}$ & & missing data \\
\hline Malta & & missing data & Montenegro & & missing data \\
\hline Serbia & & missing data & Serbia & & misisng data \\
\hline Country & Sub-region & $\begin{array}{l}\text { Index- } \\
\text { Information } \\
\text { and skills }\end{array}$ & Country & Sub-region & $\begin{array}{l}\text { Index- } \\
\text { Infrastructure }\end{array}$ \\
\hline Slovenia & $N M-E U$ & and skills 0.913 & France & NM - EU & 0.591 \\
\hline France & NM - EU & 0.749 & Libyan Arab Jamahiriya & NA & 0.532 \\
\hline Israel & ME & 0.749 & Algeria & NA & 0.386 \\
\hline Spain & $N M$ - EU & 0.709 & Italy & $N M-E U$ & 0.316 \\
\hline Greece & NM - EU & 0.682 & Spain & NM - EU & 0.250 \\
\hline Croatia & NM & 0.560 & Albania & NM & 0.233 \\
\hline Portugal & $N M-E U$ & 0.549 & Tunisia & NA & 0.225 \\
\hline Italy & NM - EU & 0.521 & Lebanon & ME & 0.210 \\
\hline Lebanon & ME & 0.505 & Israel & ME & 0.202 \\
\hline Cyprus & $N M-E U$ & 0.503 & Turkey & NM & 0.194 \\
\hline Macedonia, FYR & NM & 0.485 & Morocco & NA & 0.193 \\
\hline Malta & $N M-E U$ & 0.462 & Greece & NM - EU & 0.191 \\
\hline Jordan & ME & 0.460 & Jordan & ME & 0.175 \\
\hline Turkey & NM & 0.460 & Syrian Arab Republic & ME & 0.131 \\
\hline Serbia & NM & 0.434 & Portugal & $N M-E U$ & 0.123 \\
\hline Bosnia and Herzegovina & NM & 0.392 & Egypt & NA & 0.014 \\
\hline 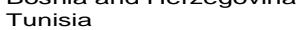 & NA & 0.351 & Bosnia and Herzegovina & & missing data \\
\hline Egypt & NA & 0.289 & Croatia & & missing data \\
\hline Albania & NM & 0.223 & Cyprus & & missing data \\
\hline Algeria & NA & 0.209 & Macedonia, FYR & & missing data \\
\hline Morocco & NA & 0.142 & Malta & & missing data \\
\hline $\begin{array}{l}\text { Libyan Arab Jamahiriya } \\
\text { Montenegro }\end{array}$ & & $\begin{array}{l}\text { missing data } \\
\text { missing data }\end{array}$ & $\begin{array}{l}\text { Montenegro } \\
\text { Serbia }\end{array}$ & & $\begin{array}{l}\text { missing data } \\
\text { missing data }\end{array}$ \\
\hline Syrian Arab Republic & & missing data & Slovenia & & misisng data \\
\hline Country & Sub-region & Index- & Country & Sub-region & $\begin{array}{l}\text { Index- } \\
\text { Equity }\end{array}$ \\
\hline Portugal & $\mathrm{NM}-\mathrm{EU}$ & 0.909 & $\overline{\text { France }}$ & NM - EU & 0.824 \\
\hline Cyprus & $N M-E U$ & 0.835 & Malta & NM - EU & 0.660 \\
\hline Italy & NM - EU & 0.819 & Cyprus & NM - EU & 0.601 \\
\hline Israel & ME & 0.812 & Italy & NM - EU & 0.592 \\
\hline Croatia & NM & 0.765 & Greece & NM - EU & 0.568 \\
\hline France & $N M-E U$ & 0.753 & Spain & NM - EU & 0.563 \\
\hline Slovenia & $N M-E U$ & 0.735 & Slovenia & NM - EU & 0.562 \\
\hline Spain & NM - EU & 0.722 & Croatia & NM & 0.515 \\
\hline Greece & NM - EU & 0.717 & Serbia & NM & 0.477 \\
\hline Malta & NM - EU & 0.690 & Portugal & $N M-E U$ & 0.403 \\
\hline Serbia & NM & 0.602 & Israel & ME & 0.360 \\
\hline Montenegro & NM & 0.572 & Egypt & NA & 0.343 \\
\hline Macedonia, FYR & NM & 0.570 & Albania & NM & 0.331 \\
\hline Turkey & NM & 0.523 & Algeria & NA & 0.266 \\
\hline Jordan & ME & 0.519 & Bosnia and Herzegovina & NM & 0.259 \\
\hline Tunisia & NA & 0.510 & Libyan Arab Jamahiriya & NA & 0.257 \\
\hline Albania & NM & 0.460 & Montenegro & NM & 0.250 \\
\hline Morocco & NA & 0.360 & Jordan & ME & 0.214 \\
\hline Algeria & NA & 0.354 & Turkey & NM & 0.137 \\
\hline Bosnia and Herzegovina & NM & 0.307 & Tunisia & NA & 0.122 \\
\hline Egypt & NA & 0.231 & Morocco & NA & 0.114 \\
\hline Libyan Arab Jamahiriya & NA & 0.182 & Macedonia, FYR & NM & 0.082 \\
\hline Syrian Arab Republic & $\mathrm{ME}$ & 0.101 & Syrian Arab Republic & ME & 0.079 \\
\hline Lebanon & $\mathrm{ME}$ & 0.087 & Lebanon & ME & 0.055 \\
\hline
\end{tabular}


Table 4 - Subjects of justice, roles, and ethical categories

\begin{tabular}{|c|c|c|c|c|c|c|c|c|}
\hline & & \multicolumn{2}{|c|}{ Farmers } & \multicolumn{2}{|c|}{ Producers Organizations } & \multicolumn{2}{|c|}{$\begin{array}{c}\text { National } \\
\text { Governments }\end{array}$} & \multirow{2}{*}{$\begin{array}{c}\text { NGOs and } \\
\text { International } \\
\text { organizations }\end{array}$} \\
\hline & & North & South & North & South & North & South & \\
\hline \multirow{2}{*}{$\begin{array}{l}\text { Roles and } \\
\text { Ethical } \\
\text { categories }\end{array}$} & $\begin{array}{l}\text { Contributors } \\
\text { (Ability to } \\
\text { Pay/Prospective } \\
\text { Responsibility) }\end{array}$ & NO & NO & YES & NO & YES & NO & $\begin{array}{c}\text { YES } \\
\text { (Indirect duty) }\end{array}$ \\
\hline & $\begin{array}{l}\text { Recipients } \\
\text { (Lack of Adaptive } \\
\text { Capacity) }\end{array}$ & NO & YES & NO & $\begin{array}{l}\text { YES } \\
\text { (Indirect } \\
\text { right) }\end{array}$ & $\mathrm{NO}$ & $\begin{array}{l}\text { YES } \\
\text { (Indirect } \\
\text { right) }\end{array}$ & NO \\
\hline
\end{tabular}

